\begin{tabular}{cc|c}
\hline & $\begin{array}{c}\text { Tarım Bilimleri Dergisi } \\
\text { Tar. Bil. Der. }\end{array}$ & Journal of Agricultural Sciences \\
& $\begin{array}{c}\text { Dergi web sayfası: } \\
\text { www.agri.ankara.edu.tr/dergi }\end{array}$ & Journal homepage: \\
& www.agri.ankara.edu.tr/journal
\end{tabular}

\title{
Effects of Pediococcus spp. on the Quality of Vacuum-Packed Horse Mackerel during Cold Storage
}

\author{
Serap COSANSU ${ }^{\mathrm{a}}$, Suhendan MOL ${ }^{\mathrm{b}}$, Didem UCOK ALAKAVUK ${ }^{\mathrm{b}}$, Ş. Yasemin TOSUN ${ }^{\mathrm{b}}$ \\ ${ }^{a}$ Sakarya University, Engineering Faculty, Department of Food Engineering, 54187, Sakarya, TURKEY \\ ${ }^{b}$ Istanbul University, Faculty of Fisheries, Department of Seafood Processing Technology, Laleli, Istanbul, TURKEY
}

ARTICLE INFO

Research Article - Agricultural Food

DOI: $10.1501 /$ Tarimbil 0000001156

Corresponding author: Suhendan MOL, e-mail: suhendan@istanbul.edu.tr, Tel: +90(212) 45557

00/16437 Received: 28 December 2010, Received in revised form: 18 March 2011, Accepted: 30 March

2011

\begin{abstract}
Horse mackerel (Trachurus trachurus, Linnaeus 1758) fillets were inoculated with bacteriocin-like metabolite producer (Group A) and non-producer (Group B) strains of Pediococcus spp. (7 log CFU g ${ }^{-1}$ ), then samples were vacuum packaged and stored $\left(4^{\circ} \mathrm{C} 10\right.$ days $\left.^{-1}\right)$. $\mathrm{pH}$ values did not display differences between the groups $(P>0.05)$. TVB-N and TMA-N values, total mesophilic and psychrophilic aerobic bacteria counts of all groups (Control, A and

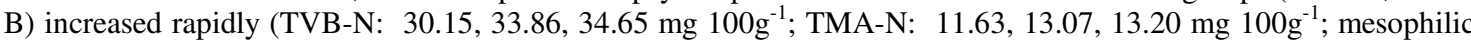
aerobic bacteria: 6.02, 6.30, $5.94 \mathrm{log} \mathrm{CFU} \mathrm{g}{ }^{-1}$; psychrophilic aerobic bacteria: 6.30, 6.24, 6.09 $\log \mathrm{CFU} \mathrm{g}^{-1}$ ), and exceeded the limits at the $2^{\text {nd }}$ day of storage. However, sensory scores of the inoculated samples were higher than that of the controls during the storage. Sensory qualities of group A and B samples were acceptable until the $6^{\text {th }}$ day, while control samples spoiled at the $4^{\text {th }}$ day. Therefore, it was concluded that sensory quality of treated samples were better, but Pediococcus strains used in this study were not proper for preserving horse mackerel fillets especially at low storage temperatures.
\end{abstract}

Keywords: Horse mackerel; Fish; Lactic acid bacteria; Pediococcus; Shelf life

\section{Vakum Paketlenmiş İstavritin Soğuk Depolamadaki Kalitesi Üzerine Pediococcus spp.'un Etkisi}

\section{ESER BİLGÍsí}

Araştırma Makalesi — Tarımsal Gıda

Sorumlu Yazar: Suhendan MOL, e-posta: suhendan @istanbul.edu.tr, Tel: +90(212) 45557 00/16437

Geliş tarihi: 28 Aralık 2010, Düzeltmelerin gelişi: 18 Mart 2011, Kabul: 30 Mart 2011

\section{ÖZET}

İstavrit (Trachurus trachurus, Linnaeus 1758) filetoları bakteriosin-benzeri metabolit üreten (A grubu) ve üretmeyen (B grubu) Pediococcus spp. ile inoküle edilmiş ( $\left.7 \mathrm{log} \mathrm{kob} \mathrm{g}^{-1}\right)$, ve daha sonra vakum paketlenerek depolanmıştır $\left(4^{\circ} \mathrm{C}\right.$ 10 gün $\left.^{-1}\right)$. Gruplar arasında $\mathrm{pH}$ değerinde önemli farklılık görülmemiştir $(P>0.05)$. Tüm deneme gruplarının (Kontrol, A, B) TVB-N, TMA-N değerleri ile toplam mezofil ve psikrofil bakteri yükleri hızla artarak (TVB-N:

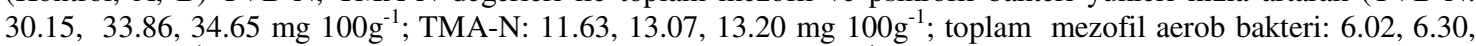
$5.94 \log \mathrm{kob} \mathrm{g}^{-1}$; toplam psikrofil bakteri: 6.30, 6.24, $6.09 \operatorname{log~kob~g}^{-1}$ ) kabul edilebilir limit değerleri depolamanın 2. gününde aşmıştır. Ancak inoküle edilmiş grupların duyusal puanları depolama süresince kontrol grubundan daha 
yüksektir. Depolamanın 6. gününe kadar A ve B grupları duyusal bakımdan kabul edilebilirken, kontrol örnekleri 4. günde bozulmuştur. Böylece inoküle edilmiş örneklerin duyusal bakımdan kontrol grubundan daha iyi olduğu, fakat kullanılan Pediococcus spp.'un istavrit filetolarının özellikle düşük sıcaklıkta muhafaza edilmesi konusunda yeterli olmadığı sonucuna varılmıştır.

Anahtar sözcükler: İstavrit; Balık; Laktik asit bakterisi; Pediococcus; Raf ömrü

도 Ankara Üniversitesi Ziraat Fakültesi

\section{Introduction}

Lactic acid bacteria (LAB) may inhibit the spoilage bacteria due to the production of a variety of antimicrobial substances. Bacteriocins, produced by LAB are biologically active proteins that have antimicrobial effect. Therefore, bacteriocinproducing $\mathrm{LAB}$ is considered as promising natural preservatives (Aymerich et al 1998; Yin et al 2002). It is possible to prevent the growth of undesirable microorganisms on refrigerated fish by inoculation with lactic acid culture (Kim \& Hearnsberger 1994). Using protective cultures maintains additivefree preservation, and biopreservation may provide an extended shelf life and enhance the safety of fish using the microflora and/or their antimicrobial products (Stiles 1996). Lactic acid bacteria may inhibit growth of undesirable microorganisms by one or synergism between several mechanisms such as lowering $\mathrm{pH}$, competition for nutrients, production of organic acids, hydrogen peroxide, gas compositions of atmosphere or antimicrobial compounds such as bacteriocins (Ray \& Deaschel 1994; Cosansu \& Ayhan 1998; Çakır \& Çakmakç1 1998; Karahan \& Çakmakçı 1998; Durlu-Ozkaya et al 2001).

In recent years many researchers have been focused on bacteriocins produced by LAB due to their antibacterial activity against food-borne bacteria (Soomro et al 2002). Comparing with antibiotics, the most important advantage of bacteriocins is their digestion in human intestine system due to their peptide structure. Thus, the ingestion of these compounds will not affect digestive tract ecology, and also will not cause risks related to the use of antibiotics (Bromberg et al 2004). The members of genus Pediococcus, which has a large group of lactic acid bacteria, are commonly used for fermentation of meat and vegetables. Bacteriocin producing Pediococcus strains are shown as good candidates not only for food processing, but also for preservation of fresh and processed foods (Pederson 1949; Chikindas et al 1993). Conditions of treatment with LAB are important to maintain shelf life extension, but there is a lack of knowledge and there are very limited publications on the effect of lactic acid bacteria on the shelf life of refrigerated fish (Kim \& Hearnsberger 1994; Kim et al 1995). For fish products the use of lactic acid bacteria is still relatively unexploited according to Jeppesen \& Huss (1993).

Horse mackerel was chosen as material in this study since it is a common fish in Mediterranean Sea (Gogus \& Kolasaric1 1992) and it is one of the fish species mostly caught in Turkish marine waters. The amount of catch has been reported as 20373 tons in 2009 (Tuik 2009). Therefore, the aim of this study was to determine the effect of a bacteriocin-like metabolite producer and a nonproducer strain of Pediococcus on the sensory, microbiological and chemical quality of vacuum packed horse mackerel during the storage at $4 \pm 1^{\circ} \mathrm{C}$.

\section{Materials and Methods}

\subsection{Materials}

Horse mackerel (Trachurus trachurus, Linnaeus 1758) samples were purchased from wholesale fish market in Istanbul. Samples were transferred to laboratory in cooled conditions and used in the same day. Pediococcus spp. cultures, which were originally isolated from fermented sausages (Cosansu et al 2007), were obtained from culture collection of Ankara University, Engineering Faculty, Department of Food Engineering. The strain Pediococcus sp. 13 sp. has been shown as a bacteriocin producer in a recent study by Altuntaş et al (2010). 


\subsection{Preparation of bacterial inoculums}

Pediococcus sp. 13 (Bac+) and Pediococcus sp. 1 (Bac-) were maintained in MRS Broth (Merck, Darmstadt, Germany) contained $15 \%$ glycerol at $40^{\circ} \mathrm{C}$. Pediococcus strains, propagated twice in MRS Broth at $30^{\circ} \mathrm{C}$ for $24 \mathrm{~h}$, were inoculated in to $100 \mathrm{ml} \mathrm{MRS} \mathrm{Broth}$ at the level of $2 \%$ and incubated at $30^{\circ} \mathrm{C}$ for $24 \mathrm{~h}$. After incubation, the cultures were centrifuged at $5000 \mathrm{rpm}$ in a Centro mix centrifuge (Selecta, Barcelona, Spain) for 10 minutes at $4^{\circ} \mathrm{C}$, supernatants were removed and the pellets were washed with sterile peptone water $(0.1 \%)$. Following washing, the supernatants were discarded and the pellets were resuspended in the flasks contained $100 \mathrm{~m} l$ sterile peptone water $(0.1 \%)$. These solutions were used for inoculation of horse mackerel fillets.

\subsection{Treatment of horse mackerel fillets by Pediococcus strains}

Horse mackerels were headed, eviscerated, and filleted. Samples were divided into three groups and first group was separated as control. The second group (group A) was inoculated with Pediococcus sp. 13 (Bac+) and the third group (group B) with Pediococcus sp. 1 (Bac-). Inoculation level was $10^{7}$ $\log \mathrm{CFU} \mathrm{g} \mathrm{g}^{-1}$. For inoculation, the inoculum was sprayed from a $10 \mathrm{~cm}$-distance to one side of each fillet and spread with sterile bent glass rod. Inoculated fillets were left to stand separately at $4^{\circ} \mathrm{C}$ for 15 minutes for inoculums attachment. The same procedure was repeated for the other side of each fillet. For all groups (Control, A and B), two fillets were inserted into vacuum bags (suitable for vacuum packaging, thickness 90 micron, oxygen permeability $160 \mathrm{cc} \mathrm{m}^{-2} \mathrm{day}^{-1}$, moisture permeability $8.50 \mathrm{cc} \mathrm{m}^{-2} \mathrm{day}^{-1}$, Polinas, Istanbul, Turkey), sealed using vacuum packaging machine (Komet, Germany), and stored at $4 \pm 1^{\circ} \mathrm{C}$ for 10 days. On each sampling day $\left(0,2,4,6,8\right.$, and $\left.10^{\text {th }}\right)$ the contents of two packages from each group were mixed and analyzed. Chemical and microbiological analyses were carried out for 4 times for each group on each sampling day and all the study was conducted as two replicates.

\subsection{Microbiological, sensorial and chemical analyses}

Samples of $10 \mathrm{~g}$ from each group were placed in sterile plastic bags, mixed with $90 \mathrm{ml}$ of peptone water $(0.1 \%)$ and homogenized for $120 \mathrm{~s}$ at 8.0 strokes $\mathrm{s}^{-1}$ (IUL Masticator, Spain) for microbiological analyses. Appropriate serial dilutions were made in $0.1 \%$ peptone water and plated by spreading $0.1 \mathrm{ml}$ on duplicate plates of Plate Count Agar (PCA, Merck, Darmstadt, Germany) for total aerobic mesophilic $\left(30^{\circ} \mathrm{C}, 48 \mathrm{~h}\right)$ and total psychrophilic $\left(7^{\circ} \mathrm{C}, 10\right.$ days $)$ counts. Lactic acid bacteria were enumerated by pour plating $1 \mathrm{ml}$ sample using MRS agar (Merck, Darmstadt, Germany) and after solidification a second layer of MRS Agar was poured onto plates to create microaerobic conditions. Then, the plates were incubated at $30^{\circ} \mathrm{C}$ for $48 \mathrm{~h}$. After incubation, the colonies were counted manually and counts were expressed as $\log \mathrm{CFU} \mathrm{g}{ }^{-1}$.

For the sensory analysis texture, smell, appearance, and taste (cooked) of the samples were evaluated by five judges experienced to estimate fish quality. The mean of these criteria was used for the sensory evaluation. Three was the highest point for the panel testing and the one point was the limit of acceptability (Ozden et al 2007). pH was measured with Hanna 211 microprocessor $\mathrm{pH}$ meter (Vyncke 1981). For TVB-N and TMA-N analyses the method described by Schormüller (1968) was used. The study was duplicated; mean values and standard deviations were presented in the manuscript and in the tables. Statistical analyses were carried out according to Sümbüloğlu \& Sümbüloğlu (2002) and ANOVA-test was performed. Standard errors were mentioned in the tables. Differences between the treatments were evaluated $(P<0.05)$ and shown in the tables.

\section{Results and Discussion}

In this study sensory scores of the inoculated samples were not different than treated ones $(P>0.05)$ at the beginning of storage (Table 1). However, treatment with lactic acid bacteria tended to be higher in sensory scores at the later stages of cold storage. Similarly, Leroi et al (1996) found no important sensory improvement for smoked salmon inoculated with lactic acid bacteria, while the sensory properties of inoculated slices became 
significantly better than the control, during the storage period. In another study, shelf life of lactic acid-added chub mackerels has been reported as 12 days, while not-treated control samples spoiled at the $9^{\text {th }}$ day (Metin et al 2001).

In our study, for the $\mathrm{pH}$ values there were no significant differences among the groups $(P=0.841)$ during storage (Table 1). Similar to our result, Djenane et al (2005) studied on the effect of lactic acid bacteria on the shelf life of beef steaks and reported no significant difference $(P>0.05)$ between the control and inoculated samples for $\mathrm{pH}$ during the storage.

It is known that total volatile bases (TVB-N) are present in even very fresh fish. Likewise, the TVB$\mathrm{N}$ content of the samples was approximately $15 \mathrm{mg}$ $100 \mathrm{~g}^{-1}$ at the beginning of storage in this study. Total volatile bases nitrogen value of $35 \mathrm{mg} 100 \mathrm{~g}^{-1}$ is regarded as the acceptability limit for seafood (Schormüller 1968; Ludorff \& Meyer 1973). In our study, all samples were below this limit until the $2^{\text {nd }}$ day, while they were above $50 \mathrm{mg} 100 \mathrm{~g}^{-1}$ at the $4^{\text {th }}$ day of storage (Table 2). During the storage, TVB$\mathrm{N}$ values increased rapidly in all groups, not correlated to sensory results, thus did not indicate the spoilage. Similarly, Leroi et al (1996) studied the effect of lactic acid bacteria on the shelf life of smoked salmon. They reported no difference between TVB-N values of control and treated samples $(P=0.881)$, while the sensory scores of treated samples were better. Therefore, they have mentioned TVB-N as a poor spoilage indicator.

In marine fish, trimethylamine oxide (TMA-O) found in large amount and it is decomposed to trimethylamine (TMA-N) by endogenous and bacterial enzymes (Ashie et al 1996). Different limit values for TMA-N were reported in various literatures. It was reported as 5-10 mg $100 \mathrm{~g}^{-1}$ by Sikorski et al (1990), $8 \mathrm{mg} 100 \mathrm{~g}^{-1}$ by Varlik et al (1993), and 10-15 mg $100 \mathrm{~g}^{-1}$ by Connell (1980). Mol et al (2007) reported TMA-N content of cold stored $\left(4^{\circ} \mathrm{C}\right)$ horse mackerels as $5 \mathrm{mg} 100 \mathrm{~g}^{-1}$ at the beginning of storage, similar to that of our study. This value reached to $17.58 \mathrm{mg} 100 \mathrm{~g}^{-1}$ on the $2^{\text {nd }}$ day and it was over $30 \mathrm{mg} 100 \mathrm{~g}^{-1}$ at the rest of storage. Likewise, TMA-N values were above 10 $\mathrm{mg} 100 \mathrm{~g}^{-1}$ after the $2^{\text {nd }}$ day of storage in our study
(Table 2), and there were no significant differences $(P=0.734)$ between TMA-N values of the groups. Similarly, Leroi et al (1996) reported TMA-N as a poor spoilage indicator since there was no difference between control and LAB-inoculated samples, even sensory scores were different.

The activity of microorganisms is important on fish spoilage and therefore enumeration of total viable counts is usually used to estimate quality of fish (Olafsdottir et al 1997). It was also reported that, psychrophilic aerobic bacteria are generally responsible for the spoilage of cold-stored foods (Mol et al 2007). Leroi et al (1996) inoculated vacuum-packed cold smoked salmon with lactic acid bacteria and reported no great difference between controls and treated samples for microbiological parameters. Similar to this finding, there were not significant differences between the control and treated groups for total mesophilic $(P=$ $0.876)$ and psychrophilic $(P=0.975)$ aerobic bacteria counts in presented study. As it was shown in Table 3, total mesophilic and psychrophilic aerobic bacteria counts increased in all groups during the storage. However, sensory scores of control and treated samples were not in parallel with microbial counts as it was also reported by Leroi et al (1996). In another study, Kim \& Hearnsberger (1994) treated catfish fillets with sodium acetate and or potassium sorbate with or without lactic culture. They reported that, samples were still marketable while they contain high amounts of gram negative bacteria at the further stages of storage.

Lactic acid bacteria (Pediococcus sp13/Bac ${ }^{+}$for group A and Pediococcus sp1/Bac for group B) were inoculated on to fish fillets at the level of $7 \mathrm{log}$ CFU $\mathrm{g}^{-1}$ in our study. This inoculation level was chosen because high inoculum levels (6-9 log CFU $\mathrm{g}^{-1}$ ) are needed for protective effect. Lactic acid bacteria counts of treated groups remained almost stable during the ten-day storage and their amounts were significantly higher $(P<0.05)$ than control group which has natural LAB load about 3-4 log CFU g ${ }^{-1}$ (data not shown). Likewise, LAB count of vacuum-packed cold smoked salmon remained at their level of inoculation during the four-week storage period at $4^{\circ} \mathrm{C}$ (Leroi et al 1996). Similarly Tanaka et al (1980) found that L. plantarum did not 
Table 1-Sensory evaluation and $\mathrm{pH}$ of horse mackerel samples during cold $\left(4^{\circ} \mathrm{C}\right)$ storage $(\mathrm{Mean} \pm \mathrm{SEM})$

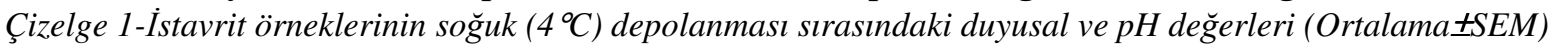

\begin{tabular}{|c|c|c|c|c|c|c|c|c|}
\hline \multirow[b]{2}{*}{ Days } & \multicolumn{3}{|c|}{ Sensory* } & \multirow[b]{2}{*}{ Mean } & \multicolumn{3}{|c|}{$p H$} & \multirow[b]{2}{*}{ Mean } \\
\hline & Control & $A\left(B a c^{+}\right)$ & $B\left(B a c^{-}\right)$ & & Control & $A\left(B a c^{+}\right)$ & $B\left(B a c^{-}\right)$ & \\
\hline 0 & $2.20 \pm 0.11$ & $2.25 \pm 0.02$ & $2.22 \pm 0.05$ & $2.22 \pm 0.02^{\mathrm{a}}$ & $6.42 \pm 0.03$ & $6.41 \pm 0.03$ & $6.44 \pm 0.03$ & $6.42 \pm 0.02^{\mathrm{a}}$ \\
\hline 2 & $1.68 \pm 0.06$ & $1.98 \pm 0.06$ & $2.03 \pm 0.16$ & $1.89 \pm 0.11^{\mathrm{a}}$ & $6.44 \pm 0.08$ & $6.56 \pm 0.02$ & $6.57 \pm 0.01$ & $6.52 \pm 0.03^{\mathrm{a}}$ \\
\hline 4 & $0.94 \pm 0.12$ & $1.44 \pm 0.13$ & $1.31 \pm 0.17$ & $1.23 \pm 0.15^{b}$ & $6.82 \pm 0.03$ & $6.82 \pm 0.01$ & $6.82 \pm 0.01$ & $6.82 \pm 0.09^{b}$ \\
\hline 6 & $0.72 \pm 0.08$ & $0.90 \pm 0.07$ & $0.82 \pm 0.08$ & $0.81 \pm 0.05^{b c}$ & $6.78 \pm 0.01$ & $6.83 \pm 0.02$ & $6.82 \pm 0.01$ & $6.81 \pm 0.08^{b}$ \\
\hline 8 & $0.59 \pm 0.04$ & $0.86 \pm 0.11$ & $0.65 \pm 0.09$ & $0.70 \pm 0.08^{c}$ & $6.83 \pm 0.04$ & $6.80 \pm 0.04$ & $6.74 \pm 0.05$ & $6.81 \pm 0.02^{b}$ \\
\hline \multicolumn{9}{|l|}{$P$ values } \\
\hline Treatment $(\mathrm{T})$ & & 0.797 & & & & 0.841 & & \\
\hline Days (D) & & 0.000 & & & & 0.000 & & \\
\hline $\mathrm{T} \times \mathrm{D}$ & & 0.659 & & & & 0.929 & & \\
\hline
\end{tabular}

* = Extra Quality $\geq 2: 7$; A Quality $2.0 \leq \mathrm{A}<2: 7$; B Quality 1.0 $\leq \mathrm{B}<2: 0$; Unacceptable $\mathrm{C}<1.0$

${ }^{\mathrm{a}-\mathrm{c}}$ : In the same column means with different letters are significantly different $(P \leq 0.05)$

Table 2-TVB-N and TMA-N values $(\mathrm{mg} / 100 \mathrm{~g})$ during cold $\left(4^{\circ} \mathrm{C}\right)$ storage (Mean \pm SEM) Çizelge 2-Soğuk $\left(4^{\circ} \mathrm{C}\right)$ depolama sırasındaki TVB-N ve TMA-N $(\mathrm{mg} / \mathrm{lo0g})$ değerleri (Ortalama \pm SEM)

\begin{tabular}{|c|c|c|c|c|c|c|c|c|}
\hline \multirow[b]{2}{*}{ Days } & \multicolumn{3}{|c|}{$T V B-N, m g 100 g^{-1}$} & \multirow[b]{2}{*}{ Mean } & \multicolumn{3}{|c|}{$T M A-N, m g 100 g^{-1}$} & \multirow[b]{2}{*}{ Mean } \\
\hline & Control & $A\left(B a c^{+}\right)$ & $B\left(B a c^{-}\right)$ & & Control & $A\left(B a c^{+}\right)$ & $B\left(B a c^{-}\right)$ & \\
\hline 0 & $15.77 \pm 1.73$ & $15.51 \pm 1.72$ & $15.65 \pm 1.73$ & $15.64 \pm 0.95^{\mathrm{a}}$ & $5.34 \pm 0.24$ & $5.34 \pm 0.24$ & $5.31 \pm 0.23$ & $5.34 \pm 0.13^{\mathrm{a}}$ \\
\hline 2 & $30.15 \pm 2.79$ & $33.86 \pm 2.12$ & $34.65 \pm 0.55$ & $32.88 \pm 1.23^{\mathrm{b}}$ & $11.63 \pm 0.23$ & $13.07 \pm 0.35$ & $13.20 \pm 1.82$ & $12.63 \pm 0.75^{b}$ \\
\hline 4 & $55.35 \pm 1.23$ & $54.24 \pm 1.11$ & $55.12 \pm 2.53$ & $54.90 \pm 0.91^{\mathrm{c}}$ & $13.69 \pm 0.19$ & $13.65 \pm 0.21$ & $13.64 \pm 0.21$ & $13.66 \pm 0.11^{\mathrm{b}}$ \\
\hline 6 & $63.89 \pm 0.63$ & $60.56 \pm 0.82$ & $60.84 \pm 0.85$ & $61.76 \pm 0.53^{d}$ & $13.59 \pm 0.21$ & $13.49 \pm 0.16$ & $13.74 \pm 0.12$ & $13.61 \pm 0.09^{b}$ \\
\hline 8 & $66.93 \pm 0.66$ & $61.67 \pm 0.73$ & $65.45 \pm 1.32$ & $64.68 \pm 0.70^{\mathrm{e}}$ & $13.25 \pm 0.36$ & $13.49 \pm 0.31$ & $12.93 \pm 1.24$ & $13.22 \pm 1.39^{b}$ \\
\hline \multicolumn{9}{|l|}{$P$ values } \\
\hline Treatment (T) & & 0.881 & & & & 0.734 & & \\
\hline Days (D) & & 0.000 & & & & 0.000 & & \\
\hline $\mathrm{T} \times \mathrm{D}$ & & 0.557 & & & & 0.965 & & \\
\hline
\end{tabular}

Table 3-Total mesophilic and psychrophilic bacteria counts $\left(\log \mathrm{CFU} \mathrm{g}^{-1}\right)$ during cold ( $\left.4^{\circ} \mathrm{C}\right)$ storage (Mean \pm SD)

Çizelge 3-Soğuk $\left(4^{\circ} \mathrm{C}\right)$ depolama sırasındaki toplam mezofilik ve psikrofilik bakteri $\left(\log C F U g^{-1}\right)$ sayıları (Ortalama $\pm S E M$ )

\begin{tabular}{|c|c|c|c|c|c|c|c|c|}
\hline \multirow[b]{2}{*}{ Days } & \multicolumn{3}{|c|}{ Mesophilic bacteria, $\log C F U g^{-1}$} & \multirow[b]{2}{*}{ Mean } & \multicolumn{3}{|c|}{ Psychrophilic bacteria, $\log C F U g^{-1}$} & \multirow{2}{*}{ Mean } \\
\hline & Control & $A\left(B a c^{+}\right)$ & $B\left(B a c^{-}\right)$ & & Control & $A\left(B a c^{+}\right)$ & $B\left(B a c^{-}\right)$ & \\
\hline 0 & $5.38 \pm 0.11$ & $5.01 \pm 0.12$ & $5.29 \pm 0.22$ & $5.22 \pm 0.09^{\mathrm{a}}$ & $5.67 \pm 0.20$ & $5.75 \pm 0.19$ & $5.47 \pm 0.28$ & $5.63 \pm 0.13^{\mathrm{a}}$ \\
\hline 2 & $6.02 \pm 0.20$ & $6.30 \pm 0.18$ & $5.94 \pm 0.11$ & $6.06 \pm 0.10^{b}$ & $6.30 \pm 0.30$ & $6.24 \pm 0.24$ & $6.09 \pm 0.24$ & $6.21 \pm 0.14^{b}$ \\
\hline 4 & $6.07 \pm 0.12$ & $6.47 \pm 0.27$ & $6.56 \pm 0.29$ & $6.36 \pm 0.14^{b}$ & $6.58 \pm 0.27$ & $6.64 \pm 0.27$ & $6.81 \pm 0.32$ & $6.68 \pm 0.16^{\mathrm{c}}$ \\
\hline 6 & $6.58 \pm 0.21$ & $6.88 \pm 0.26$ & $6.77 \pm 0.28$ & $6.74 \pm 0.14^{\mathrm{c}}$ & $6.95 \pm 0.28$ & $6.99 \pm 0.23$ & $6.94 \pm 0.29$ & $6.96 \pm 0.15^{\mathrm{c}}$ \\
\hline 8 & $7.05 \pm 0.26$ & $7.10 \pm 0.28$ & $6.94 \pm 0.25$ & $7.03 \pm 0.15^{\mathrm{c}}$ & $7.35 \pm 0.22$ & $7.42 \pm 0.18$ & $7.45 \pm 0.19$ & $7.41 \pm 0.11^{\mathrm{d}}$ \\
\hline 10 & $6.49 \pm 0.20$ & $6.81 \pm 0.13$ & $6.72 \pm 0.13$ & $6.84 \pm 0.09^{c}$ & $7.44 \pm 0.17$ & $7.48 \pm 0.13$ & $7.53 \pm 0.16$ & $7.48 \pm 0.09^{d}$ \\
\hline Mean & $6.35 \pm 0.11$ & $6.43 \pm 0.13$ & $6.37 \pm 0.12$ & & $6.71 \pm 0.13$ & $6.75 \pm 0.15$ & $6.71 \pm 0.12$ & \\
\hline \multicolumn{9}{|l|}{$P$ values } \\
\hline Treatment (T) & \multicolumn{4}{|c|}{0.876} & \multicolumn{4}{|c|}{0.975} \\
\hline Days (D) & \multicolumn{4}{|c|}{0.000} & \multicolumn{4}{|c|}{0.000} \\
\hline $\mathrm{T} \times \mathrm{D}$ & \multicolumn{4}{|c|}{0.925} & \multicolumn{4}{|c|}{1.000} \\
\hline
\end{tabular}

${ }^{\mathrm{a}-\mathrm{d}}$ : In the same column means with different letters are significantly different $(P \leq 0.05)$ 
grow at $4^{\circ} \mathrm{C}$ but survived for 21 days in meat.

In this study one of the strains (Pediococcus $\mathrm{sp}$ 13) used for the samples of group A was a bacteriocin-like metabolite producer and the other was non-producer (Cosansu et al 2007). However, as it was shown in Table 3, there was almost no difference between the groups for total mesophilic and psychrophilic aerobic bacteria counts. It could be mentioned that these strains was not capable to produce antimicrobial metabolites such as bacteriocins or lactic acid at these conditions. It is known that incubation temperature is one of the main factors that influence the bacteriocin production rate and also their activity (Rodgers 2001). Besides, Kotzekidou \& Bloukas (1996) underlined the importance of selecting the type of protective culture regarding its antimicrobial agent production ability during cold storage and the specific characteristics of product. Leroi et al (1996) inoculated cold smoked salmon with lactic acid bacteria and found no important difference between microbiological and chemical parameters of control and treated samples. Djenane et al (2005) found higher effect of $\mathrm{LAB}$ at $25^{\circ} \mathrm{C}$ than that of at lower temperatures. It is also mentioned that using LAB as preservative and/or bioprotector could be useful especially at abuse temperatures (Scott \& Taylor 1981; Signorini et al 2006; Wessels \& Huss 1996).

Einarsson \& Lauzon (1995) treated shrimps with various bacteriocins from lactic acid bacteria and reported shelf life extension except carnocin UI49. Total mesophilic and psychotropic bacteria and MRS counts of the samples treated with carnocin UI49 were not different than those of controls at $4.5^{\circ} \mathrm{C}$. Some foods may have inhibitory effect towards bacteriocins and thus reduce or eliminate their efficiency (Ganzle et al 1999). Therefore it was mentioned that LAB as protective cultures were less effective in foods than in vitro conditions (Budde et al 2003). Djenane et al (2006) studied the effect of $\mathrm{LAB}$ on shelf life of $\mathrm{CO}_{2}$-packed beef steak's microbial flora and found no significant alteration of meat quality characteristics. Kışla \& Ünlütürk (2004) studied the microbial shelf life of rainbow trout treated with lactic acid culture and lactic acid. They reported the initial load of gram- negative bacteria as $4.55 \log \mathrm{CFU} \mathrm{g}^{-1}$ and psychrophilic bacteria as $4.89 \log \mathrm{CFU} \mathrm{g}^{-1}$. These values have been reported as 4.42 and $5.29 \log \mathrm{CFU}$ $\mathrm{g}^{-1} \quad(P>0.05)$, respectively after the treatment with lactic culture. However, the count of gram-negative bacteria was $3.41 \log \mathrm{CFU} \mathrm{g}^{-1}$ and it was $4.39 \mathrm{log}$ $\mathrm{CFU} \mathrm{g}^{-1}$ for psychotropic bacteria $(P<0.05)$ in lactic acid dipped samples. They mentioned that the dipping of rainbow trout fillets into a lactic culture did not prolonged the shelf life due to the low inoculum level and type of lactic culture used. Metin et al (2001) mentioned that lactic acid increased the shelf life of chub mackerel at $4^{\circ} \mathrm{C}$. Similarly, Signorini et al (2006) suggested lactic acid as the most efficient treatment for controlling spoilage populations. However, effect of treatment with lactic acid bacteria considered as an additional factor parallel to other preservation methods.

\section{Conclusions}

Ineffectiveness of both LAB strains used in this study could be attributed to low storage temperature. In other words, inoculated Pediococcus strains survived well on the surface of horse mackerel samples, but could not produce enough antimicrobial metabolites such as lactic acid, hydrogen peroxide and bacteriocin to inhibit spoilage flora.

\section{References}

Altuntas E G, Cosansu S \& Ayhan K (2010). Some growth parameters and antimicrobial activity of a bacteriocin-producing strain Pediococcus acidilactici 13. International Journal of Food Microbiology 141: 28-31

Ashie N A, Smith J P \& Simpson B K (1996). Spoilage and shelf life extension of fresh fish and shellfish. Critical Reviews in Food Science and Nutrition 36: 87-121

Aymerich M T, Hugas M \& Monfort J M (1998). Review: Bacteriocinogenic lactic acid bacteria associated with meat products. Food Science and Technology International 4: 141-158

Budde B B, Hornbeak T, Jacobsen T, Barkholt V \& Koch A G (2003). Leuconostoc carnosum 4010 has the potential as a new protective culture for vacuum packed meats: culture isolation, bacteriocin 
identification and meat application. International Journal of Food Microbiology 83: 171-184

Bromberg R, Moreno I, Zaganini C L, Delboni R R \& De Oliviera J (2004). Isolation of bacteriocin-producing lactic acid bacteria from meat and meat products and its spectrum of inhibitory activity. Brazilian Journal of Microbiology 35: 137-144

Chikindas M L, Garcia-Garcera M J, Driessen A J M, Ledeboer A M, Nissen-Meyer J, Nes I F, Abee T, Konings W N \& Venema G (1993). Pediocin PA-1, a bacteriocin from Pediococcus acidilactici PAC1.0, forms hydrophilic pores in the cytoplasmic membrane of target cells. Applied Environmental Microbiology 59: 3577-3584

Connel J J (1980). Control of Fish Quality. $2^{\text {nd }}$ Fishing New Books Ltd. Farnham, Surrey, England, pp. 116139

Cosansu S \& Ayhan K (1998). Fermente et ürünlerinde starter kültür kullanımı ile patojenlerin inhibisyonu. Gida 23: 99-103

Cosansu S, Kuleaşan H, Ayhan K \& Materon L (2007). Antimicrobial activity and protein profiles of Pediococcus spp. isolated from Turkish sucuk. Journal of Food Processing 31: 190-200

Çakır İ \& Çakmakçı M L (1998). Et tavuklarının körbarsak florasında yer alan laktobasillerin proteolitik aktiviteleri ve organik asit oluşturma yeteneklerinin belirlenmesi. Tarım Bilimleri Dergisi 4(3): $53-58$

Djenane D, Martinez L, Blanco D, Yangüela J, Beltran J A \& Roncales P (2005). Effect of Lactic acid bacteria on extension of shelf life and growth of Listeria monocytogenes in beef steaks stored in $\mathrm{CO}_{2}-\mathrm{Rich}$ Atmosphere. Brazilian Journal of Microbiology 36: 405-412

Djenane D, Martinez L, Sanchez-Escalante A, Montanes L, Blanco D, Yangüela J, Beltran J A \& Roncales P (2006). Effect of lactic acid bacteria on beef steak microbial flora stored under modified atmosphere and on Listeria monocytogenes in broth cultures. Food Science and Technology Resources International 12: 287-295

Durlu-Ozkaya F, Xanthopoulos V, Tunail N \& Litopoulou-Tzanetaki E (2001). Technologically important properties of lactic acid bacteria isolates from Beyaz cheese made from raw ewes' milk. Journal of Applied Microbiology 91: 861-870

Einarsson H \& Lauzon H L (1995). Biopreservation of brined shrimp (Pandalus borealis) by bacteriocins from Lactic acid bacteria. Applied Environmental

\section{Microbiology 61: 669-676}

Ganzle M G, Weber S \& Hammes W P (1999). Effect of ecological factors on the inhibitory spectrum and activity of bacteriocins. International Journal of Food Microbiology 46: 207-217

Gogus A K \& Kolsarici N (1992). Seafood Technology. Ankara University, Publication of Agriculture Faculty, No: 1243, p. 226

Jeppesen V F \& Huss H H (1993). Characteristics and antagonistic activity of lactic acid bacteria isolated from chilled fish products. International Journal of Food Microbiology 18: 305-320

Karahan A G \& Çakmakçı M L (1998). Körbarsaktan izole edilen lactobacillus suşlarının bazı özelliklerinin belirlenmesi. Tarım Bilimleri Dergisi 4(3): 59-64

Kişla D \& Ünlütürk A (2004). Microbial shelf life of rainbow trout fillets treated with lactic culture and lactic acid. Advances in Food Science 26: 17-20

Kim C R \& Hansberger J O (1994). Gram negative bacteria inhibition by lactic acid culture and food preservatives on catfish fillets during refrigerated storage. Journal of Food Science 59: 513-516

Kim C R, Hansberger J O, Vickery A P, White C H \& Marshall D L (1995). Sodium acetate and bifidobacteria increase shelf life of refrigerated catfish fillets. Journal of Food Science 60: 25-27

Kotzekidou P \& Bloukas J G (1996). Effect of protective cultures and packaging film permeability on shelf life of sliced vacuum packaged cooked ham. Meat Science 42: 333-345

Leroi F, Arbey N, Joffraud J J \& Chevalier F (1996). Effect of inoculation with lactic acid bacteria on extending the shelf life of vacuum-packed cold smoked salmon. International Journal of Food Science and Technology 31: 497-504

Ludorff W \& Meyer V (1973). Fische und Fischerzeugnisse, Paul Parey Verlag, HamburgBerlin, Germany, p.95-111, 176-269

Metin S, Erkan N, Varlik C \& Aran N (2001). Extension of the chub mackerel (Scomber scombrus, Houttuyn 1780) treated with lactic acid. EuropeanFood Resources and Technology 213: 174-177

Mol S, Erkan N, Üçok D \& Tosun Ş Y (2007). Effect of psychrophilic bacteria to estimate fish quality. Journal of Muscle Foods 18: 120-128

Olafsdottir G, Martinsdottir E, Oehlenschlager J, Dalgaard P, Jensen B, Undeland I, Mackie I M, Henehan G, Nielsen J \& Nielsen H (1997). Methods to evaluate fish freshness in research and industry. Trends in Food Science and Technology 81: 258-265 
Ozden O, Inugur M \& Erkan N (2007). Effect of different dose gamma radiation and refrigeration on the chemical and sensory properties and microbiological status of aquacultured sea bass (Dicentrarchus labrax). Radiation Physics and Chemistry 76: 1169-1178

Pederson C S (1949). The genus Pediococcus. Bacteriology Reviews 13: 225-232

Ray B, Daeschel M (1994). Bacteriocins of starter culture bacteria. In: M Dillon \& G Board (Eds.), Natural antibacterial systems and food preservation, CAB International, Oxon UK, pp. 133

Rodgers S (2001). Preserving non-fermented refrigerated foods with microbial cultures- a review. Trends in Food Science and Technology 12: 276-284

Schormüller J (1968). Handbuch Der Lebensmittel Chemie; Band III/2Teil In: Tiersiche Lebensmittel Eier, Fleisch, Buttermilch, Springer Verlag, Berlin Heidelberg-New York, pp. 1341-1397, 1561, 1578, 1584

Scott V N \& Taylor S L (1981). Effect of nisin on the outgrowth of Clostridium botulinum spores. Journal of Food Science 46: 117-120

Signorini M L, Ponce-Alquicira E \& Guerrero-Legarreta I (2006). Effect of lactic acid and lactic acid bacteria on growth of spoilage microorganisms in vacuumpackaged beef. Journal of Muscle Foods 17: 277-290

Sikorski Z E, Kolakowska A \& Burt J R (1990). Postharvest biochemical and microbiological changes. In: ZE Sikorski (Ed.), Seafood: Resources Nutritional Composition and Preservation, CRC Press Inc., Boca Raton, Florida, pp. 55-76

Soomro A H, Masud T \& Anwaar K (2002). Role of lactic acid bacteria (LAB) in food preservation and human health- a review. Pakistan Journal of Nutrition 1: 20-24

Stiles M (1996). Biopreservation by lactic acid bacteria. Antonie van Leeuwenhoek 70: 331-345

Sümbüloğlu K \& Sümbüloğlu V (2002). Biyoistatistik. Hatipoğlu Basım ve Yayım San. ISBN: 975-7527-122.10 Ankara, Turkey

Tanaka N, Trasman E, Lee M H, Cassens R G \& Foster E M (1980). Inhibition of botulinum toxin formation in bacon by acid development. Journal of Food Protection 43: 450-457.

TUIK (2009). Fishery Statistics Prime Ministry Republic of Turkey" Turkish Statistical Institute. Available at: http://tuikrapor.tuik.gov.tr/reports/rwservlet?hayvanci lik
Varlik C, Ugur M, Gökoglu N \& Gün H (1993). Su ürünlerinde kalite kontrol ilke ve yöntemleri. Gida Teknolojisi Dernegi, İstanbul, Turkey

Vyncke W (1981). Twelfth Western European Fish Technologists' Association (WEFTA) Meeting. Copenhagen: WEFTA

Wessels S \& Huss HH (1996). Suitability of Lactococcus lactis subsp. lactis ATCC 11454 as a protective culture for lightly preserved fish products. Food Microbiology 13: 323-332

Yin L J, Pan, C L \& Jiang S T (2002). Effect of lactic acid bacterial fermentation on the characteristics of minced mackerel. Journal of Food Science 67: 786792 